\title{
The Influence of Cadmium Stress on the Content of Mineral Nutrients and Metal-Binding Proteins in Arabidopsis halleri
}

\author{
Ewa Przedpelska-Wąsowicz • Aleksandra Polatajko • \\ Malgorzata Wierzbicka
}

Received: 10 March 2012 / Accepted: 25 July 2012 /Published online: 23 August 2012

(C) The Author(s) 2012. This article is published with open access at Springerlink.com

\begin{abstract}
We investigated the influence of cadmium stress on zinc hyperaccumulation, mineral nutrient uptake, and the content of metal-binding proteins in Arabidopsis halleri. The experiments were carried out using plants subjected to long-term cadmium exposure (40 days) in the concentrations of 45 and $225 \mu \mathrm{M}$ $\mathrm{Cd}^{2+}$. Inductively coupled plasma-mass spectrometry, size exclusion chromatography coupled with plasmamass spectrometry, and laser ablation inductively coupled plasma-mass spectrometry used for ablation of polyacylamide gels were employed to assess the content of investigated elements in plants as well as to identify metal-binding proteins. We found that $A$. halleri is able to translocate cadmium to the aerial parts in high amounts (translocation index $>1$ ). We showed that $\mathrm{Zn}$ content in plants decreased significantly with the increase of cadmium content in the growth medium. Different positive and negative correlations between $\mathrm{Cd}$
\end{abstract}

Electronic supplementary material The online version of this article (doi:10.1007/s11270-012-1292-4) contains supplementary material, which is available to authorized users.

E. Przedpełska-Wąsowicz $(\bowtie) \cdot M$. Wierzbicka Department of Molecular Plant Physiology, Institute of Botany, Faculty of Biology, University of Warsaw, Miecznikowa 1, 02-096 Warsaw, Poland e-mail: przedpelska@biol.uw.edu.pl

A. Polatajko

ISAS-Institute for Analytical Sciences,

P.O. Box 101352, 44013 Dortmund, Germany content and mineral nutrients were evidenced by our study. We identified more than ten low-molecularweight $(<100 \mathrm{kDa})$ Cd-binding proteins in Cd-treated plants. These proteins are unlikely to be phytochelatins or metallothioneins. We hypothesize that lowmolecular-weight Cd-binding proteins can be involved in cadmium resistance in $A$. halleri.

Keywords Arabidopsis halleri · Cadmium . Cadmium-binding proteins $\cdot$ Hyperaccumulator . Metal accumulation $\cdot$ Zinc

$\begin{array}{ll}\begin{array}{l}\text { Abbreviations } \\ \text { ICP-MS }\end{array} & \begin{array}{l}\text { Inductively coupled plasma-mass } \\ \text { spectrometry } \\ \text { Laser ablation inductively coupled } \\ \text { plasma-mass spectrometry }\end{array} \\ \text { LA-ICP-MS } & \text { Low molecular weight } \\ \text { LMW } & \text { Polyacrylamide gel electrophoresis } \\ \text { PAGE } & \begin{array}{l}\text { Polyvinylpyrrolidone } \\ \text { PVP }\end{array} \\ \text { SEC-ICP-MS } & \begin{array}{l}\text { Size exclusion chromatography } \\ \text { coupled with plasma-mass } \\ \text { spectrometry }\end{array}\end{array}$

\section{Introduction}

Arabidopsis halleri (Brassicaceae) is a perennial species occurring in Europe and East Asia (Al-Shehbaz and O'Kane 2002). Apart from natural mountainous habitats, it occurs also in areas polluted with heavy 
metals (Ernst 1990; Pauwels et al. 2006). The species is well known for its' tolerance to zinc and cadmium and the ability to hyperaccumulate these metals. A. halleri, a close wild relative of Arabidopsis thaliana, is a model species in studies focused on the problem of metal tolerance and hyperaccumulation in plants (Pauwels et al. 2006; Verbruggen et al. 2009; Maestri et al. 2010; Meyer et al. 2010, 2011; Gode et al. 2012).

Many studies have investigated zinc hyperaccumulation in plants (Lasat and Kochian 1998, 2000; Pauwels et al. 2006; Broadley et al. 2007; Verbruggen et al. 2009; Maestri et al. 2010; Meyer et al. 2010). In case of cadmium hyperaccumulation, however, the problem seems to be less studied. Hitherto, only four species are known to hyperaccumulate cadmium. Since these plants are also zinc hyperaccumulators, it suggests a common genetic basis of both phenomena (Verbruggen et al. 2009). Nonetheless, little is known regarding correlation between hyperaccumulation of zinc and cadmium.

Zinc and cadmium belong to the most intensively studied metals in terms of their impact on plants. Zinc is a micronutrient essential to plant growth; however, its excess can cause toxic effects. Cadmium is one the most frequent and the most dangerous inorganic pollutants. Although both metals share similar chemical properties (they have similar atomic radius, similar oxidation state in chemical compounds, and share similar geochemical properties), cadmium shows higher tendency to bond with sulfur and higher mobility in soils and in whole ecosystems (Emsley 1991; Kabata-Pendias 2010). It has been hypothesized that both metals can share similar pathway while entering the plant organism (Zhao et al. 2006). In contrast to zinc, which is essential for plant growth, cadmium is not found in any natural chemical compound in living organisms. Cadmium is widely studied in the context of environmental pollution and its' impact on human health (di Toppi and Gabbrielli 1999). Although the metal is toxic to plants, it is known for its easy uptake (Kabata-Pendias 2010). Strong affinity to sulfhydryl groups is one of the most important biochemical characteristics of cadmium. The metal, however, can also easily bind to functional groups containing nitrogen or oxygen (Polatajko et al. 2007).

Research on metal-chelating compounds in organisms responsible for the metal homeostasis of the cell showed that different chemical compounds can be involved in this process including amino acids (e.g., histidine, nicotiamine), organic acids such as: malate and citric acid, phytochelatins, and metallothioneins (Szpunar 2005; Fenik et al. 2007; Polatajko et al. 2007; Maestri et al. 2010). Braude et al. (1980) mentioned that cadmium shows a tendency to accumulate in a protein fraction within the plant cell. This is particularly interesting, as most of the proteins regulating metal homeostasis of the plant cell, are also involved in detoxification, regulation of the cell cycle, proliferation, and apoptosis (Garcia et al. 2006). To understand thoroughly plant response to environmental stress caused by metal ions, it is necessary to localize, identify, and quantify metal-containing macromolecules. This task is particularly challenging from the analytical point of view. Hyphenated techniques for biological systems such as size exclusion chromatography coupled with plasma-mass spectrometry (SEC-ICP-MS) or laser ablation inductively coupled plasma-mass spectrometry (LA-ICP-MS) can be regarded as a solution of this problem. Recently, this technique was used for direct ablation of polyacrylamide gels (PAGE) (Szpunar 2005; Fenik et al. 2007; Polatajko et al. 2007).

We employed these techniques in order to investigate the influence of the $\mathrm{Cd}$ stress on mineral nutrient uptake and metal-binding proteins content in $A$. halleri.

We tested the following hypotheses:

1. A. halleri is a Cd hyperaccumulator.

2. There is a correlation between Cd uptake and the content of mineral nutrients.

3. Cd ions are bound by low-molecular-weight $(<100 \mathrm{kDa})$ metal-binding proteins.

\section{Materials and Methods}

\subsection{Plant Material}

Experiments were carried out using $A$. halleri plants. Seeds were obtained from the $\mathrm{Pb} / \mathrm{Zn}$ mining area in Boleslaw near Olkusz (S Poland), a region highly polluted with heavy metals (Przedpelska and Wierzbicka 2007; Abratowska et al. 2012). Plants were cultivated for 40 days in growth chamber under controlled temperature conditions $\left(24 \pm 4{ }^{\circ} \mathrm{C}\right)$, relative humidity of $65 \pm$ $4 \%$, light intensity of $\sim 120 \mu \mathrm{mol} / \mathrm{m}^{2} / \mathrm{s}$, and photoperiod of $8: 16 \mathrm{~h}$. 


\subsection{Plant Cultivation and Metal Exposure}

Seeds collected from the field were germinated in Petri dishes on filter paper moistened with diluted Knop nutrient solution (1:8 dilution) supplemented with A$\mathrm{Z}$ mixture of trace elements (Strebeyko 1967), in the light at the temperature of $24{ }^{\circ} \mathrm{C} \pm 1{ }^{\circ} \mathrm{C}$. About 7 days old, seedlings were transferred into pot boxes containing perlite as a substrate. The perlite was washed daily with Knop's nutrient solution of the following chemical composition-200 g/l Ca $\left(\mathrm{NO}_{3}\right)_{2} \times 4 \mathrm{H}_{2} \mathrm{O}, 71.5 \mathrm{~g} / 1 \mathrm{KNO}_{3}, 35.5 \mathrm{~g} / \mathrm{K} \mathrm{KCl}, 71.5 \mathrm{~g} /$ $1 \mathrm{MgSO}_{4}, 71.5 \mathrm{~g} / 1 \mathrm{KH}_{2} \mathrm{PO}_{4}, 28 \mathrm{~g} / 1$ EDTA-Fe, and trace elements (including $\mathrm{Zn}^{2+}$ at the concentration of $0.4 \mu \mathrm{M}), \mathrm{pH}=6$.

The plants were divided into control group and two experimental groups (30 plants each). Experimental groups were treated every second day with cadmium added to the nutrient solution as $\mathrm{Cd}\left(\mathrm{NO}_{3}\right)_{2} \times 4 \mathrm{H}_{2} \mathrm{O}$ to achieve the concentrations of 45 and $225 \mu \mathrm{M} \mathrm{Cd}^{2+}$. $\mathrm{Cd}$ concentrations employed were chosen on the basis of pilot experiments (data not shown). We intended to use $\mathrm{Cd}$ doses that would enable plants to accumulate maximal amount of $\mathrm{Cd}$ in their tissues without visible effects of toxicity. Forty-day-old plants were harvested, divided into shoot and root portions, and then washed several times in distilled water. By the shoot portions, all the aerial portions of plant including stem and leaves are meant. To ensure complete removal of all the components of the growth medium (including $\mathrm{Cd}^{2+}$ ), roots were washed for $5 \mathrm{~min}$ in $20 \mathrm{mM}$ EDTA. Subsequently, samples were immediately frozen in liquid nitrogen and ground using a pestle and mortar. To avoid protein unfolding and a loss of metals from their native structures, samples were placed on dry ice after grounding. A part of the sampled material was used in protein extraction, and the remaining portion was lyophilized.

\subsection{Quantification of Cd, Zn, and Mineral Nutrients}

For quantification of the total metal content, $0.2 \mathrm{~g}$ of lyophilized leaf and $0.1 \mathrm{~g}$ of root samples were digested with $6 \mathrm{~mL}$ of a $\mathrm{HNO}_{3}-\mathrm{H}_{2} \mathrm{O}$ mixture (5:1) using a microwave-assisted digestion with closed vessels (Anton Paar, Graz, Austria). Triplicate extracts from all the samples were taken. Digested samples were diluted with Milli-Q water to $50 \mathrm{~mL}$ and analyzed by ICP-MS using an external calibration curve with $\mathrm{Rh}$
(10 $\mathrm{n} \mathrm{mL}^{-1}$ ) as an internal standard. The double focusing sector field ICP-MS (ELEMENT 2, ThermoFisher Scientific, Bremen, Germany) coupled to the Cetac autosampler (ASX-500, Omaha, Nebraska, USA) was used for multi-element analysis $(\mathrm{Cd}, \mathrm{Zn}, \mathrm{Mg}, \mathrm{S}, \mathrm{Mn}, \mathrm{Fe}$, $\mathrm{Cu}, \mathrm{Mo}$ ). Translocation index was calculated as described by Branquinho et al. (2007). Statistical significance of the observed differences between the control and experimental groups was tested by Kruskal-Wallis test using Statistica 9.1. Shape of the distribution within analyzed groups and the variance were checked prior to the analysis in order to ensure that the assumption of the homoscedasticity of the data is not broken. To test for correlations between cadmium and other analyzed elements, we used coefficient of determination $\left(R^{2}\right)$. Regression lines and $95 \%$ confidence intervals were calculated. Significance tests were carried out at $5 \%$ significance level. All the statistical analyses were performed using Statistica 9.1 (Statsoft Inc.)

\subsection{Protein Extraction}

Proteins were extracted from shoots and roots of the control and Cd-treated plants following the sample preparation protocol $-5 \mathrm{~g}$ of leaves and $3 \mathrm{~g}$ of roots were homogenized with $6 \mathrm{~mL}$ of $50 \mathrm{mM}$ HEPES-NaOH (pH 7.6) containing $2 \%$ PVP and protease inhibitor cocktail (Complete, EDTA-free) using a ultrasonic probe homogenization technique (Branson, SONIFIER, Schwäbisch Gmünd, Germany). The homogenization method involved $5 \times 30$-s treatments until a wellhomogenized extract was obtained. In order to obtain cytosol free from organelle samples were centrifuged at $105,000 \mathrm{~g}$ for $1 \mathrm{~h}$ at $4{ }^{\circ} \mathrm{C}$ using a Sorvall Discovery 90SE ultracentrifuge (ThermoFisher, Dreieich, Germany). The supernatant was then centrifuged for $30 \mathrm{~min}$ at 4,000 rpm using a Heraeus SEPATECH centrifuge (ThermoFisher, Dreieich, Germany). The aliquots were stored at $-80{ }^{\circ} \mathrm{C}$ for further investigations. The method employed has been optimized by Polatajko et al. (2011).

\subsection{SEC-ICP-MS Analysis of Leaves and Roots Extracts}

Cadmium-protein complexes from shoots and roots extracts were probed by size exclusion chromatography (SEC, Dionex, Germering, Germany) coupled to ICPMS (ELEMENT 2, Thermo Fisher Scientific, Bremen, Germany). SEC-purified fraction was also used for 
identification of $\mathrm{Zn}$ - and $\mathrm{Cu}$-proteins. The method employed has been optimized by Polatajko et al. (2011).

\subsection{PAGE-LA-ICP-MS Analysis of Leaves and Roots Extracts}

The separation of cadmium-containing proteins was done by using anodal native $10 \%$ polyacrylamide gel electrophoresis (1D AN-PAGE) with a discontinuous Tris/Tricine system according to the manufacturer's instructions. A Nd:YAG laser (Minilight II, Continuum, Santa Clara, USA) coupled to the sector filed ICP-MS was used for laser ablation (LA) of the Cd-binding proteins on the membrane. For a detailed description of the background of the chemical analyses, the reader is referred to Polatajko et al. (2007).

\section{Results}

\subsection{The Influence of Cadmium on Biomass Production}

Cd-treated plants showed no signs that could be associated with the toxic effect of $\mathrm{Cd}$ ions. Leaves showed no signs of chlorosis or necrosis; tissues were well hydrated (no signs of decreased turgidity). No signs of growth inhibition or differences in development were recorded between control and treated plants. Mean dry weight of shoots was 2.2, 1.8, and $1.65 \mathrm{~g}$ for the control and two experimental groups, respectively. Mean dry weight of roots was $0.3,0.3$, and $0.27 \mathrm{~g}$, respectively. Nevertheless, there was no significant difference in biomass production between control and treated plants, regardless of the concentration of $\mathrm{Cd}$ in the growth medium (Kruskal-Wallis test, $p=$ 0.1955 for shoot samples, $p=0.3594$ for root samples).

The above-mentioned observations show that $A$. halleri is tolerant to tested cadmium doses. The fact that no signs of toxicity were observed while $A$. halleri accumulated $\mathrm{Cd}$ in its tissues in high amounts (particularly in shoots, see below) additionally confirms this notion.

\section{2 $\mathrm{Cd}$ and $\mathrm{Zn}$ Accumulation}

Results obtained for quantitative multi-element analysis relative to the dry mass are presented in Fig. 1a, b. Results showed that cadmium concentration in experimental plants (40 days of treatment) increased with increasing concentration of the metal in growth medium in leaves as well as in roots (Fig. 1a). In plants treated with lower dose of cadmium $\left(45 \mu \mathrm{M} \mathrm{Cd}^{2+}\right)$, concentration of the metal in roots was $265 \mu \mathrm{g} \mathrm{g}^{-1} \mathrm{~d}$.w., whereas in plants treated with the higher dose $\left(225 \mu \mathrm{M} \mathrm{Cd}^{2+}\right)$, it was $835 \mu \mathrm{g} \mathrm{g}^{-1} \mathrm{~d}$.w. We found that in treated plants cadmium concentration in shoots was $940 \mu \mathrm{g} \mathrm{g}^{-1} \mathrm{~d}$.w. and $2,525 \mu \mathrm{g} \mathrm{g}^{-1} \mathrm{~d} . \mathrm{w}$, respectively, for lower and higher dose. Total concentration of the metal in treated plants was always higher in shoots than in roots.

The translocation index, calculated by dividing the concentration of the metal in shoots by the concentration of the metal in roots, varied narrowly between 3 and 3.5 for both tested cadmium doses.

Experiments showed that that zinc content in cadmiumtreated plants was significantly lower (Fig. 1b). While in the control group zinc content was $175 \mu \mathrm{g} \mathrm{g}^{-1}$ d.w., in treated plants, it decreased by $37 \%$ and $70 \%$ in case of lower $\left(45 \mu \mathrm{M} \mathrm{Cd}^{2+}\right)$ and higher $\left(225 \mu \mathrm{M} \mathrm{Cd}^{2+}\right)$ cadmium dose, respectively. In roots, zinc content followed the same pattern being the highest in control plants (125 $\mu \mathrm{g} \mathrm{g}^{-1}$ d.w.) and decreasing by $58 \%$ and $71 \%$ in both cadmium-treated groups. The $\mathrm{Zn}$ root-shoot translocation index calculated for each experimental group was 1.2 and 2.1, respectively.

The values of the translocation indices showed hyperaccumulation of both tested metals ( $\mathrm{Cd}$ and $\mathrm{Zn}$ ) by $A$. halleri. There was no significant difference in accumulation between investigated isotopes: ${ }^{112} \mathrm{Cd}$ vs. ${ }^{114} \mathrm{Cd}$ and ${ }^{66} \mathrm{Zn}$ vs. ${ }^{68} \mathrm{Zn}$.

\subsection{The Relationships Between Cd and Mineral Nutrient Concentrations in Shoots and Roots}

Statistical analysis showed the presence of significant correlations between the concentration of cadmium and other macro- $(\mathrm{Mg}, \mathrm{S})$ and microelements $(\mathrm{Mn}$, $\mathrm{Fe}, \mathrm{Cu}, \mathrm{Zn}, \mathrm{Mo})$. Correlation analysis uncovered that significant and strong negative correlation exists between concentrations of zinc and cadmium $\left(R^{2}=\right.$ $-0.8487, p<0.05$ in roots; $R^{2}=-0.9922, p<0.05$ in shoots). Magnesium showed significant correlation with cadmium concentration in both roots and shoots, however, in roots, the coefficient of determination showed negative $\left(R^{2}=-0.9125, p<0.05\right)$, whereas in shoots positive $\left(R^{2}=0.8765, p<0.05\right)$ value. No other investigated element showed significant correlation with cadmium concentration in roots at the significance level of $5 \%$. In shoots, significant correlations were also found between cadmium and manganese 
Fig. 1 Total concentration of $\mathrm{Cd}(\mathbf{a})$ and $\mathrm{Zn}(\mathbf{b})$ in $A$. halleri extracts from shoots and roots, respectively. Metal concentration was quantified using ICP-MS
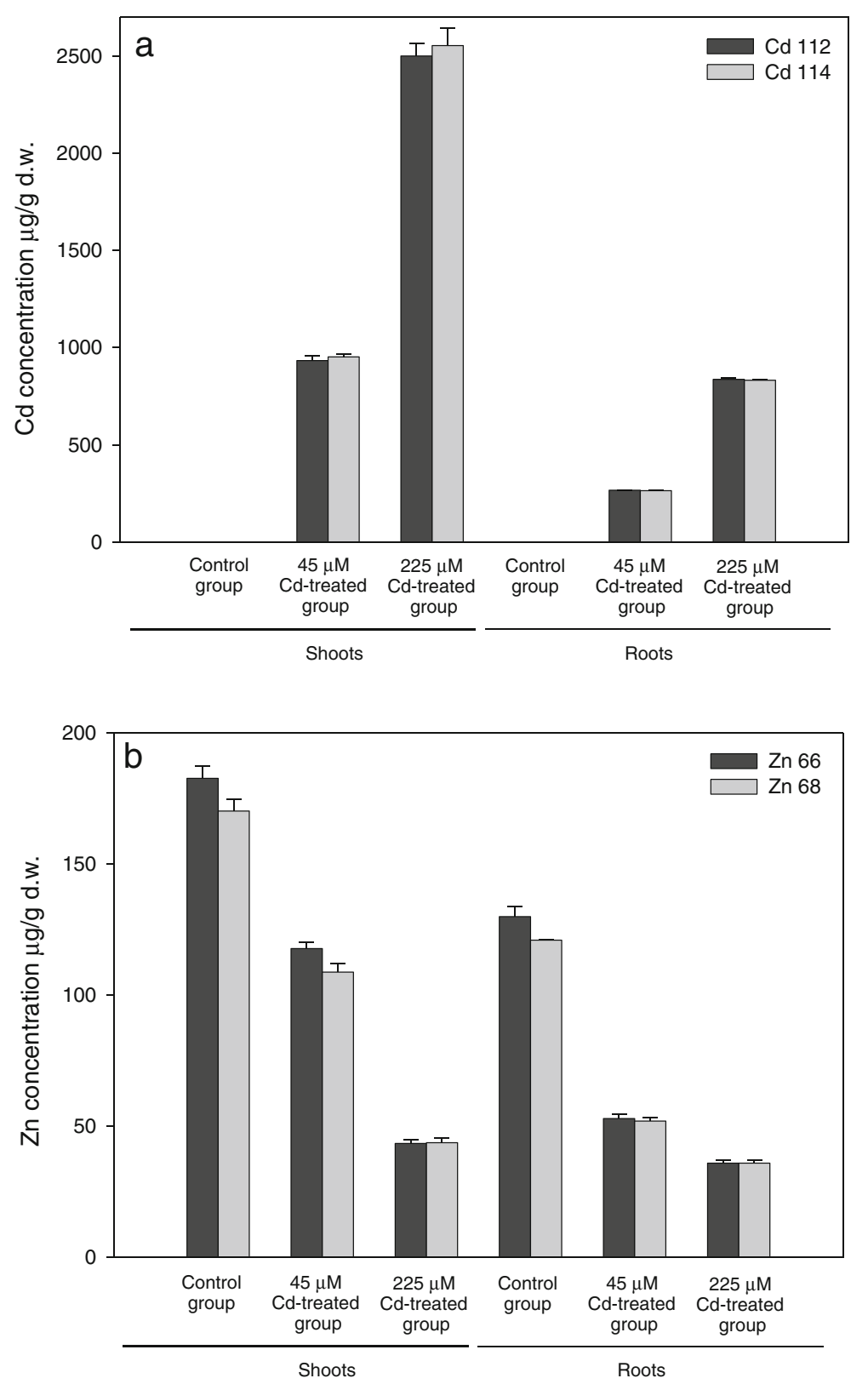

$\left(R^{2}=0.9593, p<0.05\right)$, cadmium and iron $\left(R^{2}=\right.$ $-0.8046, p<0.05)$, as well as between cadmium and copper $\left(R^{2}=-0.7307, p<0.05\right)$. There was no significant correlation between cadmium and sulfur $\left(R^{2}=0.2593, p>0.05\right.$ in roots, $R^{2}=0.1064, p>0.05$ in shoots). Regression lines along with coefficients of determination $\left(R^{2}\right)$ and results of significance testing for each analyzed element can be found in electronic supplementary material (Fig. ESM 1, Fig. ESM 2).

\subsection{Cd-Binding Proteins}

Using ICP-MS, we measured the content of Cdbinding proteins in shoots and roots. We found that, in plants treated with $45 \mu \mathrm{M} \mathrm{Cd}$, the content of $\mathrm{Cd}$ binding proteins was about 8.6 and $9.6 \mu \mathrm{g} / \mathrm{g}$ f.w. in shoots and roots, respectively. In plants treated with $225 \mu \mathrm{M} \mathrm{Cd}$, these values were about 52.5 and $33.5 \mu \mathrm{g} / \mathrm{g}$ f.w., respectively. We did not record the presence of Cd-binding proteins in the control group. 
The control electropherograms (Fig. 2a, d) showed the lack of Cd-binding proteins in both shoots and roots. Application of SEC-ICP-MS enabled us to detect one signal for Cd-binding protein in roots (Fig. 2b) as well as in shoots (Fig. 2e), during the examination of the plant material treated with $45 \mu \mathrm{M}$
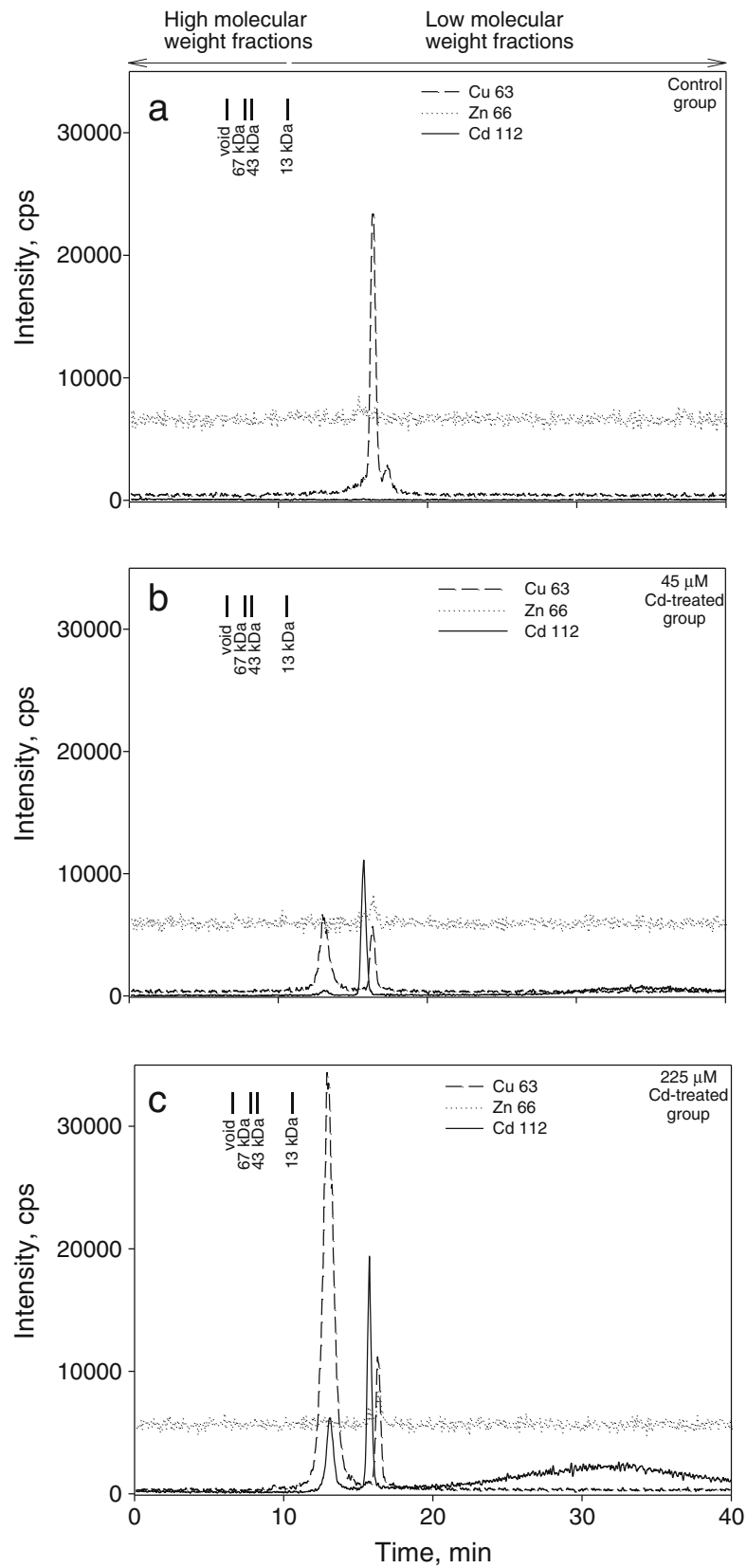

Fig. 2 a-f SEC-ICP-MS electropherogram of ${ }^{112} \mathrm{Cd}^{+},{ }^{66} \mathrm{Zn}^{+}$, and ${ }^{64} \mathrm{Cu}^{+}$intensity in A. halleri extracts from roots [control plants (a), plants treated with $45 \mu \mathrm{M} \mathrm{Cd}(\mathbf{b})$, plants treated with $225 \mu \mathrm{M} \mathrm{Cd}(\mathbf{c})$ ], and shoots [control plants (d), plants treated
$\mathrm{Cd}^{2+}$. The same methodology enabled us to detect two signals and one broad peak showing the presence of Cd-binding proteins in roots and shoots obtained from plants treated with $225 \mu \mathrm{M}$ solution of cadmium (Fig. 2c, f). All the identified Cd-proteins had small molecular weight of $<13 \mathrm{kDa}$. Apart from Cd-proteins,
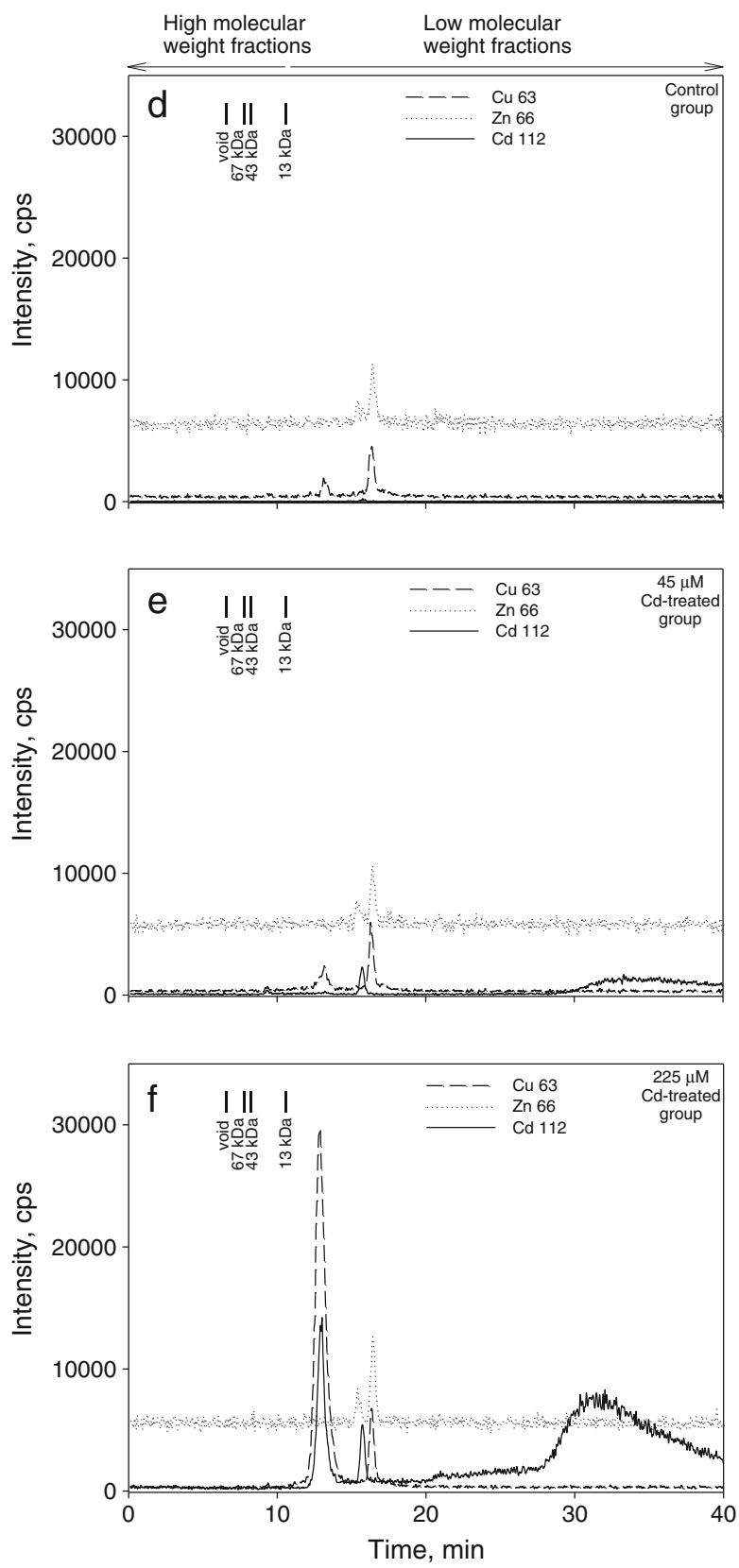

with $45 \mu \mathrm{M} \mathrm{Cd}(\mathbf{e})$, plants treated with $225 \mu \mathrm{M} \mathrm{Cd}(\mathbf{f})]$. The signal from ${ }^{112} \mathrm{Cd}^{+}$is designated by the solid line; the signal from ${ }^{66} \mathrm{Zn}^{+}$is designated by the dashed line, and the signal from ${ }^{64} \mathrm{Cu}^{+}$is designated by the dotted line 
two clear signals for Zn-binding proteins were also recorded in shoot extracts from of Cd-treated plants (Fig. 2a-f). We also recorded two signals of $\mathrm{Cu}-$ binding proteins in all the analyzed extracts (Fig. 2a-f). One of the $\mathrm{Cu}$-binding proteins was eluted together with one of the Cd-binding protein (Fig. 2c, f). Both $\mathrm{Cu}-$ binding proteins identified by us showed low molecular weight of $<13 \mathrm{kDa}$. It should be noted that intensity of the signal from the bigger protein increased with the increase of cadmium content in growth medium in samples from roots and shoots. The intensity of the signal from the smaller $\mathrm{Cu}$-binding protein was smaller in $\mathrm{Cd}$ treated than in control plants in roots. In shoots, signal intensity from the smaller molecule did not differ so strongly. We noticed that intensity of the signal from Zn-binding protein increased slightly in samples treated with the highest dose of cadmium.

Application of PAGE-LA-ICP-MS (laser ablation inductively coupled plasma-mass spectrometry used for ablation of polyacylamide gels) enabled us to record Cd-binding proteins with higher resolution than the one offered by SEC-ICP-MS (Fig. 3a, b). Figure 3a presents electropherogram of Cd-binding proteins in roots. In samples treated with $45 \mu \mathrm{M} \mathrm{Cd}^{2+}$, signal below $75 \mathrm{kDa}$ is smeared and looks like a distribution of the metal through the gel. In roots of plants treated with $225 \mu \mathrm{M}$ $\mathrm{Cd}^{2+}$, four bands at $35,25,20$, and $\sim 19 \mathrm{kDa}$ were recorded. In leaves from Cd-treated plants (regardless
Fig. 3 SDS-PAGE gel stained with Coomassie blue (right panels) and ${ }^{112} \mathrm{Cd}^{+}$intensity for PAGELA-ICP-MS (left panels) of A. halleri extracts from roots (a) and from shoots (b)
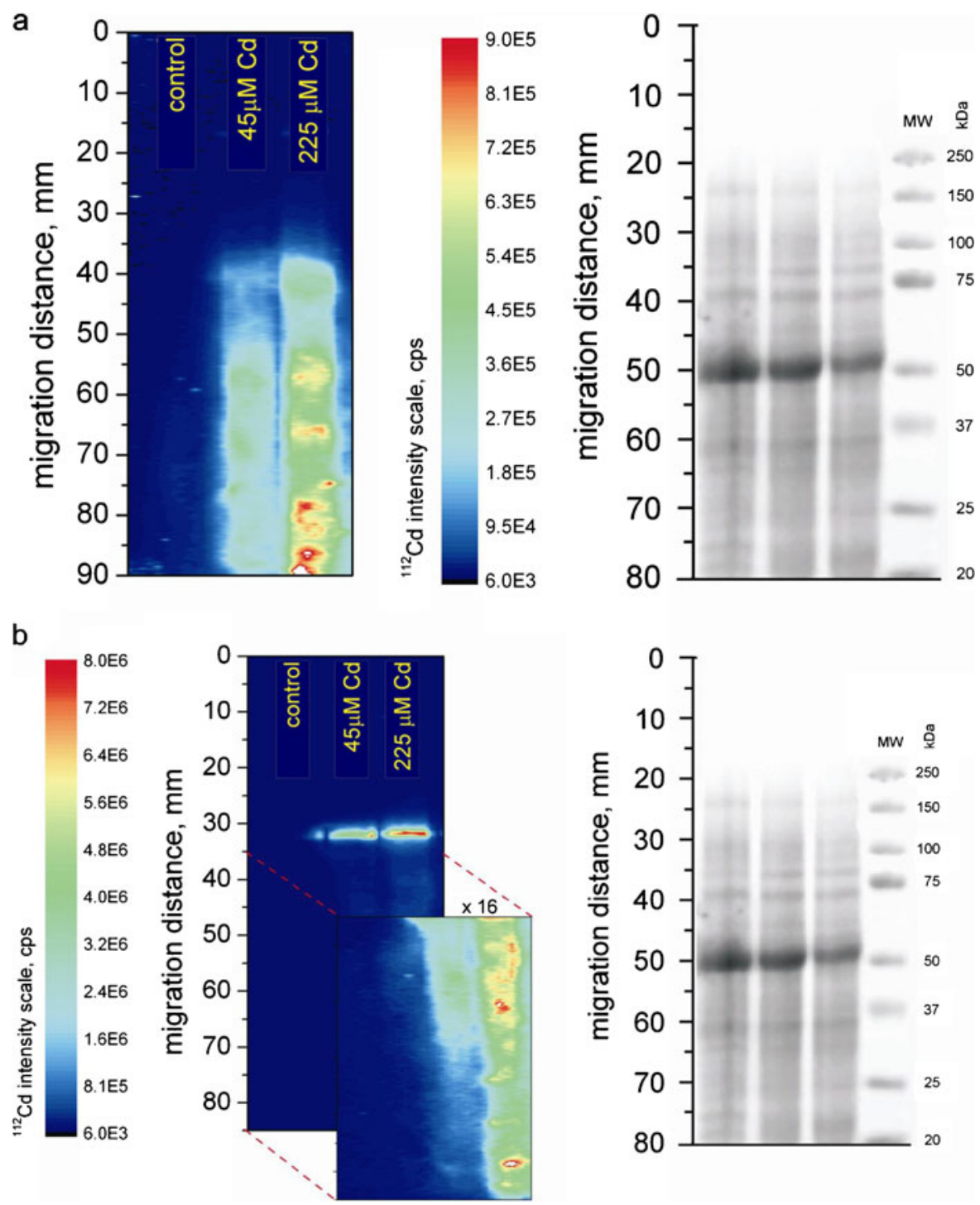
the dose applied), one band at $\sim 75 \mathrm{kDa}$ was recorded (Fig. 3b). Additionally, two bands at 50 and $20 \mathrm{kDa}$ were recorded in leaf extracts from plants treated with $225 \mu \mathrm{M}$ $\mathrm{Cd}^{2+}$ (Fig. 3b).

We showed for the first time that Cd-binding proteins with low molecular weight $(<100 \mathrm{kDa})$ are present in A. halleri and that the amount of $\mathrm{Cd}$ bound to these proteins correlated with the amount of the metal in the growth medium. The presence of two $\mathrm{Zn}$ - and two $\mathrm{Cu}$-binding proteins were recorded in control and metal-exposed plants.

\section{Discussion}

\subsection{Experimental Conditions}

Our experiments were carried out employing perlite and relatively long metal treatment using cadmium doses mimicking concentrations of this metal found in polluted soils (Nriagu and Pacyna 1988; Nriagu 1996; Yanai et al. 2006). During pilot experiments (data not shown), we tried to adjust cadmium dose in such a way as to avoid the emergence of visible toxic effects like chlorosis, necrosis, or decreased biomass production. Di Toppi and Gabbrielli (1999) indicate that growth conditions play crucial role in experiments focused on cadmium tolerance in plants. According to them, Cd tolerance in higher plants is a natural or artificially given capacity, regulated by interactions between genetic and environmental factors, to bear high levels of $\mathrm{Cd}$ exposure for a long time, without appreciable detrimental effects on metabolism. It seems that employing short-term Cd treatment leads to activation of more or less efficient detoxification mechanism that is present in all higher plants (di Toppi and Gabbrielli 1999). Application of long-term Cd treatment (i.e., chronic stress) gives an opportunity to get insights into plant response in which all the homeostatic mechanisms of the cell are involved. In that way, we are able to assess the real level of $\mathrm{Cd}$ tolerance in a given species. From all the above-mentioned reasons, we decided to employ long-term (40 days) treatment with cadmium spanning almost the entire life cycle of investigated plants (from a seedling to the mature organism).

\subsection{Cd Accumulation}

Although A. halleri is a well-known zinc hyperaccumulator, its status as a cadmium hyperaccumulator was uncertain until recently. It has been shown that $A$. halleri has a potential to hyperaccumulate cadmium (DahmaniMuller et al. 2000; Bert et al. 2002). Recently, a growing number of experimental studies confirms the ability of the plant to hyperaccumulate cadmium (Bert et al. 2003; Cosio et al. 2004; Zhao et al. 2006; Verbruggen et al. 2009; Maestri et al. 2010). The majority of abovementioned studies, however, were carried out in hydroponics and employed short-term cadmium exposure in high doses.

Our results have shown that $A$. halleri is able to accumulate cadmium up to $1,000 \mu \mathrm{g} \mathrm{g}^{-1} \mathrm{~d}$.w. in roots and up to $2,500 \mu \mathrm{g} \mathrm{g}^{-1} \mathrm{~d}$.w. in shoots without any visible symptoms of phytotoxicity. Similar Cd content in shoots (2,700 $\mathrm{mg} \mathrm{kg}^{-1}$ d.w.) was obtained by Küpper et al. (2000) under laboratory conditions. Interestingly, however, Küpper et al. (2000) and Bert et al. (2003) showed that $\mathrm{Cd}$ content in shoots was lower than in roots. Similar pattern of Cd translocation has been observed in Thlaspi caerulescens by Lombi et al. (2000) and Zhao et al. (2006). We suppose that difference in the pattern of $\mathrm{Cd}$ translocation might have been caused by different growing conditions. Küpper et al. (2000), Lombi et al. (2000), Bert et al. (2003), and Zhao et al. (2006) carried out their experiments employing hydroponic approach, while we have grown plants using perlite as a semi-hydroponic culture system and long-term cadmium exposure.

Moreno-Jimenez et al. (2007) have summarized results concerning different patterns of mercury translocation in plants depending on the type of substrate used during cultivation. They showed that root to shoot translocation of the metal was significantly higher in plants grown in perlite when compared with those grown under hydroponic conditions. Our data seem to support these observations.

Also, Vazquez and Carpena-Ruiz (2005), MorenoJimenez et al. (2007), and Sobrino-Plata et al. (2009) have noticed that the type of substrate used during cultivation significantly affects the uptake of heavy metals. The abovementioned authors paid particular attention to the differences between classic hydroponics and perlite-based cultivation system. It seems that growing plants in almost completely inert substrate such as perlite mimics well the conditions for root growth found in natural soils (Olympios 1999; Robbins and Evans 2005) including adequate humidity, stimulation of root growth, etc. (Moreno-Jimenez et al. 2007; Sobrino-Plata et al. 2009). At the same time, access to nutrients and heavy metals is more 
limited under perlite cultivation than in pure hydroponic conditions (Sobrino-Plata et al. 2009). Küpper et al. (2000), Lombi et al. (2000), Bert et al. (2003), and Zhao et al. (2006) showed that A. halleri accumulated $\mathrm{Cd}$ in the amounts higher than $0.01 \%$ d.w., what has been suggested as a criterion for Cd hyperaccumulation by Brooks (1998). Our results agree with these findings. We have also shown, however, that the plant is able to translocate the metal from roots to shoots in such a way that the ratio of the metal content in roots and in shoots is higher than 1 . This criterion of metal hyperaccumulation has been proposed by McGrath and Zhao (2003).

\subsection{The Correlation Between $\mathrm{Cd}$ and $\mathrm{Zn}$}

Hyperaccumulation

Cd hyperaccumulation has been shown in all known Zn hyperaccumulating plants. This suggests that genetic basis of both phenomena might be, at least partially, the same (Verbruggen et al. 2009). Our results indicate negative correlation between $\mathrm{Cd}$ and $\mathrm{Zn}$ content in both shoots and roots in A. halleri. The higher content of cadmium was recorded; the lower was the content of zinc.

The same phenomenon, suggesting a competition between zinc and cadmium, has been also observed by Zhao et al. (2006). On the basis of an experiment carried out during 3 weeks under hydroponic conditions, they demonstrated that increase in $\mathrm{Zn}$ content in the growth medium caused decrease in $\mathrm{Cd}$ content in plants. Investigating the effect of $\mathrm{Zn}$ and $\mathrm{Cd}$ treatment on the content of these metals in plant tissues, Küpper et al. (2000) showed that increase in $\mathrm{Zn}$ concentration caused the decrease of cadmium content in shoots by $50 \%$. The existence of a competition between $\mathrm{Zn}$ and $\mathrm{Cd}$ has been also evidenced by Cosio et al. (2004), who demonstrated that increased amount of $\mathrm{Cd}$ in the growth medium reduced $\mathrm{Zn}$ accumulation.

An important difference between the authors cited above and our experiments is that, in our study, concentration of $\mathrm{Zn}$ in the growth medium remained on constant level of $0.4 \mu \mathrm{M}$ and was similar to the concentration found in natural, unpolluted soils (Grimme 1968).

Our results seem to support the hypothesis put forward by Zhao et al. (2006) that A. halleri is able to hyperaccumulate $\mathrm{Cd}$ through the $\mathrm{Zn}$ pathway and that, in case of increased $\mathrm{Cd}$ content in the growth medium, $\mathrm{Zn}$ is accumulated in lower amounts due to the competition between both metals.
4.4 The Correlation Between Cd and Mineral Nutrient Accumulation

It has been shown that the influence of cadmium on the content of mineral nutrients in plants can depend on the concentration of cadmium, growth conditions, species, or ecotype being investigated or even on plant organ under study (Zhang et al. 2002; Cai et al. 2010). Interactions between cadmium and essential mineral elements have been studied in potatoes (Gonçalves et al. 2009), different ecotypes of wheat (Zhang et al. 2002), several Cd-tolerant, and non-tolerant ecotypes of rice (Liu et al. 2003; Cai et al. 2010), in Betula pendula - a pioneer species colonizing post-industrial polluted areas (Gussarsson et al. 1996) as well as in cadmium hyperaccumulators: Brasica juncea (Jiang et al. 2004), T. caerulescens (Roosens et al. 2003), and Sedum alfredii (Yang et al. 2004). This wide literature reveals, however, a very complicated and often contradictory picture of the problem.

In the present work, we show for the first time that cadmium influences the uptake of mineral nutrients in A. halleri. Our data show that the content of cadmium and mineral nutrients $\mathrm{Mg}^{2+}, \mathrm{Mn}^{2+}, \mathrm{Fe}^{2+}, \mathrm{Cu}^{2+}$, and $\mathrm{Zn}^{2+}$ ) was significantly correlated. At the same time, the content of mineral nutrients recorded by us in investigated plants ranged within normal limits for wild plants (Kabata-Pendias 2010). It seems from the above-mentioned reasons that correlations between the content of cadmium and mineral nutrients might not be an effect of a simple specific competition between these elements but rather an outcome of the mechanism involved in maintaining ion homeostasis. It can be hypothesized that the ability to tolerate and hyperaccumulate heavy metals by $A$. halleri may result from the ability of the species to maintain ion homeostasis under cadmium stress.

\subsection{Analysis of Metal-Binding Proteins}

It is estimated that about $40 \%$ of all proteins contain heavy metal ion in their structure (Garcia et al. 2006). Metal-containing proteins may be divided into two groups: metalloproteins and metal-binding proteins. The first group is characterized by strong affinity between protein and metal ion. The second group shows significantly weaker affinity between the two types of molecules. This fact makes the analysis of metal binding proteins an extremely difficult task as 
metals can be easily lost during the procedure of sample preparation. Hence, it is necessary here to employ chemical techniques of high resolution for protein separation and identification. In our research, we used SEC-ICP-MS and PAGE-LA-ICP-MS. Both methods are widely accepted as useful techniques for bioinorganic speciation analysis (Szpunar 2005; Garcia et al. 2006; Polatajko et al. 2007, 2011). SEC-ICP-MS enabled us to identify dominant coordination complexes of cadmium of molecular weight lower than $13 \mathrm{kDa}$ in treated plants. New-generation columns applied in SEC-ICP-MS enable the researcher to identify intact coordination complexes (Persson et al. 2006). The multi-elemental capacity of the method is one of its major advantages (Persson et al. 2006; Polatajko et al. 2011). We employed this tool to elucidate the problem whether, apart from $\mathrm{Cd}$, other important elements (such as $\mathrm{Zn}$ and $\mathrm{Cu}$ ) can also interact with proteins. In our case, the use of SEC-ICP-MS enabled us to identify proteins forming coordination complexes with the following isotopes: ${ }^{112} \mathrm{Cd},{ }^{66} \mathrm{Zn}$, ${ }^{63} \mathrm{Cu}$. SEC-ICP-MS has, however, some limitations in resolution when compared with other techniques (Persson et al. 2006). The application of size exclusion chromatography together with inductively coupled plasma mass spectrometry enabled us, however, to detect and identify metal binding proteins in $A$. halleri.

The application of PAGE-LA-ICP-MS enabled us to identify more cadmium-binding proteins with higher molecular weight, alongside with relatively small cadmium loss during experimental procedures. Cd-binding proteins identified using this method ranged between 19 and $75 \mathrm{kDa}$. It is now widely accepted that PAGE-LAICP-MS is a powerful tool in research on metal binding complexes in plant material rich in proteins (Polatajko et al. 2011). One important limitation of the technique is, however, that multi-elemental analysis is not possible on a single-blot membrane. The method, however, allowed the detection of some rare Cd-proteins with resolution significantly better than the one offered by SEC-ICPMS. These investigations allowed us to show that longterm cadmium exposure alters the protein composition of a plant.

Investigation of metal-binding proteins requires a lot of effort and the use of advanced methods. Studies in this subject should be focused on the structure and biological role of these proteins. It seems to us that the first and the most important step on this way is to localize and quantify the content of metal-binding macromolecules and to conduct their preliminary identification. Our research is an important contribution to the problem.

\subsection{Metal-Binding Proteins}

We showed for the first time that control and Cdtreated plants of $A$. halleri differ significantly at molecular level. Studies carried out hitherto were focused mainly on the isolation and identification of $\mathrm{Cd}$ binding proteins (e.g., Bartolf et al. 1980; Rauser 1984; Kumar and Prasad 2004; Kastenholz 2006; Fenik et al. 2007; Polatajko et al. 2007, 2011). Our study enabled us not only to identify these proteins but also to show that the pattern of their occurrence differ between control and Cd-treated plants, as well as between groups treated with different doses of cadmium. These differences were shown in plants without any signs of $\mathrm{Cd}$ toxicity. We think that this finding gives a new perspective on the phenomenon of metal hyperaccumulation.

In Cd-treated plants, we identified Cd-binding proteins of low molecular weight (LMW): several proteins of $<13 \mathrm{kDa}$, proteins of 20,25 , and $50 \mathrm{kDa}$, and of about $19,35,45$ and $75 \mathrm{kDa}$ in size. In control plants, we did not record the presence of these molecules, which can suggest that Cd-binding proteins are involved in plant response to cadmium. Fenik et al. (2007) showed the presence of numerous Cd-binding proteins in Cd-resistant lines of Nicotiana plumbaginifolia. They showed the presence of LMW Cdbinding proteins of 19,34 , and $40 \mathrm{kDa}$ and five proteins of $<13 \mathrm{kDa}$ in size in Cd-treated plants. In cadmium-sensitive $A$. thaliana, the presence of highmolecular-weight Cd-binding protein of approximately $200 \mathrm{kDa}$ in size has been recorded by Kastenholz (2006). The presence of LMW Cd-binding proteins in Cd-tolerant ecotypes treated with cadmium can be considered as an indirect proof of the significance of these molecules in plant response to cadmium stress.

Our experiments showed that the amount of Cdproteins correlated with the amount of $\mathrm{Cd}$ present in the growth medium. Study carried out by Kumar and Prasad (2004) showed also that there is a positive correlation between $\mathrm{Cd}$ bioaccumulation and the concentration of Cd-binding proteins. Hence, application of long-term $\mathrm{Cd}$ exposure instead of short-term, "acute" treatment seems to be more appropriate to the authors, as it should promote Cd-protein synthesis. 
Our results evidenced also the presence of LMW $(<13 \mathrm{kDa}) \mathrm{Cu}-$ and $\mathrm{Zn}$-binding proteins in A. halleri. It suggests the presence of specific proteins with very low molecular weight and high affinity to divalent metal ions in investigated plants. It seems that two metabolically important metal ions $\left(\mathrm{Cu}^{2+}\right.$ and $\left.\mathrm{Zn}^{2+}\right)$ can form complexes with proteins similar to $\mathrm{Cd}$ binding proteins, as they were characterized by almost identical elution time in size exclusion chromatography. On the basis of our studies, however, it is difficult to answer whether $\mathrm{Cd}, \mathrm{Cu}$, and $\mathrm{Zn}$ bind to the same or different proteins.

Identification of Cd-binding proteins in A. halleri can be of importance in our understanding of the mechanisms of cadmium tolerance and hyperaccumulation in plants. It has been shown that Cd-binding proteins can contain cysteine or histidine (Mejare and Bulow 2001). Both amino acids form complexes with metal ions relatively easily by binding to the thiol group in case of the former or to nitrogen from imidazole functional group (that can easily form coordination bonds with metal cations) in case of the latter.

It is known that cysteine-rich proteins such as metallothioneins and phytochelatins form stable complexes with cadmium (Mejare and Bulow 2001; Fenik et al. 2007; Meyer et al. 2011). Hitherto, numerous studies stressed the importance of phytochelatins (oligomers of glutathione) in plant response to heavy metals (e.g., di Toppi and Gabbrielli 1999; Szpunar 2005; Memon and Schroder 2009; Meyer et al. 2011). It is usually accepted that molecular weight of $\mathrm{Cd}$-phytochelatin complexes range between 2.5 and $10 \mathrm{kDa}$, depending on the plant species and physiological status of investigated specimens (Persson et al. 2006). It is also widely accepted that this mechanism of $\mathrm{Cd}$ detoxification plays a key role in Cd-sensitive ecotypes (Ebbs et al. 2002). In case of tolerant plants, or Cd hyperaccumulators such as $A$. halleri, the role of phytochelatins is almost negligible (Ebbs et al. 2002; Fenik et al. 2007; Meyer et al. 2011). It seems, therefore, that amino acids in the form of glutathione could be involved in the protection against oxidative stress caused by heavy metal ions. In this case, other molecules have to act as detoxification agents. For all the above-mentioned reasons, it seems to us that $\mathrm{Cd}$ binding proteins of molecular weight $<13 \mathrm{kDa}$ cannot be interpreted as phytochelatins.

Metallothioneins are another group of chemical compounds that are thought to play role in plant resistance to cadmium (e.g., Mejare and Bulow 2001).
Molecular weight of Cd-metallothionein complexes range between 6 and $7 \mathrm{kDa}$ (Sabolic et al. 2002). Mejare and Bulow (2001), however, put forward the hypothesis that the expression of cysteine-free metal chelating proteins is less toxic for cells than the expression of cysteine-rich molecules. According to them, this scenario is particularly relevant for plants in which synthesis of such molecules is controlled by a constitutive promoter and it is not adjusted by the metal concentration inside the cell (Mejare and Bulow 2001). Moreover, Gussarsson (1994) showed that increase in sulfur content under cadmium stress was correlated with the increased content of some Cdbinding peptides containing sulfur. We showed that sulfur content in treated plants was not correlated with $\mathrm{Cd}$. Therefore we think, that molecules of the molecular weight $<13 \mathrm{kDa}$ cannot be associated with metallothioneins. Hence, there are premises that, in small proteins identified by us, $\mathrm{Cd}$ is not bound by sulfhydryl groups that are common in phytochelatins and metallothioneins.

It is widely known that histidine can act as a very efficient ligand for metal ions such as $\mathrm{Cd}^{2+}, \mathrm{Zn}^{2+}, \mathrm{Cu}^{2+}$, $\mathrm{Ni}^{2+}$, and $\mathrm{Co}^{2+}$ (Wierzbicka et al. 2007; Verbruggen et al. 2009). This amino acid is also thought to be one of the most important compounds responsible for the chelation of metal ions in hyperaccumulators (Haydon and Cobbett 2007; Verbruggen et al. 2009). Additionally, our previous research on the speciation of $\mathrm{Cd}$ in Allium cepa epidermal cells showed the presence of specific cadmium ligand - the histidine (Wierzbicka et al. 2007). This can suggest that LMW proteins identified by us and able to bind Cd could contain histidine - the amino acid playing a key role in heavy metal detoxification in hyperaccumulators. This hypothesis requires, however, further studies and evaluation.

It is worth noting that all the investigated plants showed high level of Cd-tolerance and differed significantly in terms of the pattern of Cd-binding proteins. This can suggest that these proteins can be involved in cadmium detoxification as it was suggested previously by several authors (Fenik et al. 1995; Woolhouse 1983; Meyer et al. 2011).

\section{Conclusions}

We showed that $A$. halleri is able to translocate $\mathrm{Cd}$ to aerial parts in high amounts (translocation index $>1$ ) 
that confirmed its status as Cd hyperaccumulator. Our experiments showed that $\mathrm{Cd}$ influenced the uptake of different mineral nutrients. Our results suggest that $\mathrm{Cd}$ and $\mathrm{Zn}$ can be hyperaccumulated by $A$. halleri through a common pathway. The data obtained by us point out that $\mathrm{Cd}$ is bound by low-molecular-weight metalbinding proteins of the molecular mass $<100 \mathrm{kDa}$. These proteins are unlikely to be phytochelatins or metallothioneins. We hypothesize that these proteins can play a role in broadly understood Cd detoxification process in $A$. halleri.

Acknowledgments The authors would like to thank two anonymous reviewers for their comments that improved our manuscript and to Dr. Pawel Wasowicz, for critically reading the paper.

Open Access This article is distributed under the terms of the Creative Commons Attribution License which permits any use, distribution, and reproduction in any medium, provided the original author(s) and the source are credited.

\section{References}

Abratowska, A., Wassowicz, P., Bednarek, P., Telka, J., \& Wierzbicka, M. (2012). Morphological and genetic distinctiveness of the metallicolous and non-metallicolous populations of Armeria maritima s. 1. (Plumbaginaceae) in Poland. Plant Biology, 14, 586-595.

Al-Shehbaz, I. A., \& O'Kane, S. L., Jr. (2002). Taxonomy and phylogeny of Arabidopsis (Brassicaceae). The Arabidopsis Book. doi:10.1199/tab.0009.

Bartolf, M., Brenna, E., \& Price, C. A. (1980). Partial characterization of a cadmium-binding protein from the roots of cadmium-treated tomato. Plant Physiology, 66, 438-441.

Bert, V., Bonnin, I., Saumitou-Laprade, P., de Laguerie, P., \& Petit, D. (2002). Do Arabidopsis halleri from nonmetallicolous populations accumulate zinc and cadmium more effectively than those from metallicolous populations? New Phytologist, 155, 47-57.

Bert, V., Meerts, P., Saumitou-Laprade, P., Salis, P., Gruber, W., \& Verbruggen, N. (2003). Genetic basis of Cd tolerance and hyperaccumulation in Arabidopsis halleri. Plant and Soil, 249, 9-18.

Branquinho, C., Serrano, H. C., Pinto, M. J., \& Martins-Loucao, M. A. (2007). Revisiting the plant hyperaccumulation criteria to rare plants and earth abundant elements. Environmental Pollution, 146, 437-443.

Braude, G. L., Nash, A. M., Wolf, W. J., Carr, R. L., \& Chaney, R. L. (1980). Cadmium and lead content of soybean products. Journal of Food Science, 45, 1187-1199.

Broadley, M. R., White, P. J., Hammond, J. P., Zelko, I., \& Lux, A. (2007). Zinc in plants. New Phytologist, 173, 677-702.

Brooks, R. R. (1998). Plants that hyperaccumulate heavy metals: their role in phytoremediation, microbiology, archaeology, mineral exploration, and phytomining. Oxford- New York: CAB International.
Cai, Y., Lin, L., Cheng, W., Zhang, G., \& Wu, F. (2010). Genotypic dependent effect of exogenous glutathione on $\mathrm{Cd}$-induced changes in cadmium and mineral uptake and accumulation in rice seedlings (Oryza sativa). Plant, Soil and Environment, 56, 516-525.

Cosio, C., Martinoia, E., \& Keller, C. (2004). Hyperaccumulation of cadmium and zinc in Thlaspi caerulescens and Arabidopsis halleri at the leaf cellular level. Plant Physiology, 134, 716-725.

Dahmani-Muller, H., van Oort, F., Gelie, B., \& Balabane, M. (2000). Strategies of heavy metal uptake by three plant species growing near a metal smelter. Environmental Pollution, 109, 231-238.

di Toppi, L. S., \& Gabbrielli, R. (1999). Response to cadmium in higher plants. Environmental and Experimental Botany, 41, 105-130.

Ebbs, S., Lau, I., Ahner, B., \& Kochian, L. (2002). Phytochelatin synthesis is not responsible for Cd tolerance in the $\mathrm{Zn}$ / $\mathrm{Cd}$ hyperaccumulator Thlaspi caerulescenes (J. and C. Presl). Planta, 214, 635-640.

Emsley, J. (1991). Oxford chemistry guides the elements. Oxford: Clarendon.

Ernst, W. (1990). Mine vegetation in Europe. In J. Shaw (Ed.), Heavy metal tolerance in plants: Evolutionary aspects (pp. 21-37). Boca Raton: CRC Press.

Fenik, S. I., Trofimyak, T. B., \& Blyum, Y. B. (1995). Mechanisms of development of plant tolerance to heavy metals. Uspekhisovremennolbiologii, 115, 259-275.

Fenik, S. I., Solodushko, V. G., Kalinyak, T. B., \& Blume, A. B. (2007). The role of Cd-binding proteins and phytochelatins in the formation of cadmium resistance in Nicotiana plumbaginifolia cell lines. Cytology and Genetics, 41, 9-15.

Garcia, J. S., de Magalhaes, C. S., \& Arruda, M. A. Z. (2006). Trends in metal-binding and metalloprotein analysis. Talanta, 69, 1-15.

Gode, C., Decombeix, I., Kostecka, A., Wąsowicz, P., Pauwles, M., Courseaux, A., \& Saumitou-Laprade, P. (2012). Nuclear microsatellite loci for Arabidopsis halleri (Brassicaceae), a model species to study plant adaptation to heavy metals. American Journal of Botany, 99(2), e49-e52.

Gonçalves, J. F., Antes, F. G., Maldaner, J., Pereira, L. B., Tabaldi, L. A., Rauber, R., et al. (2009). Cadmium and mineral nutrient accumulation in potato plantlets grown under cadmium stress in two different experimental culture conditions. Plant Physiology and Biochemistry, 47, 814-821.

Grimme, H. (1968). Adsorption of $\mathrm{Mn}, \mathrm{Co}, \mathrm{Cu}$ and $\mathrm{Zn}$ by goethite from dilute solutions. Zeitschrift für Pflanzenernährung und Bodenkunde, 121, 58-65.

Gussarsson, M. (1994). Cadmium-induced alterations in nutrient composition and growth of Betula pendula seedlings: The significance of fine root as a primary target for cadmium toxicity. Journal of Plant Nutrition, 17, 2151-2163.

Gussarsson, M., Asp, H., Adalsteinsson, S., \& Jensén, P. (1996). Enhancement of cadmium effects on growth and nutrient composition of birch (Betula pendula) by buthioninesulphoximine (BSO). Journal of Experimental Botany, 47, 211-215.

Haydon, M. J., \& Cobbett, C. S. (2007). Transporters of ligands for essential metal ions in plants. New Phytologist, 174, 499-506.

Jiang, X. J., Luo, Y. M., Liu, Q., Liu, S. L., \& Zhao, Q. G. (2004). Effects of cadmium on nutrient uptake and translocation by Indian mustard. Environmental Geochemistry and Health, 26, 319-324. 
Kabata-Pendias, A. (2010). Trace elements in soils and plants. Boca Raton: CRC Press.

Kastenholz, B. (2006). Comparison of the electrochemical behavior of the high molecular weight cadmium proteins in Arabidopsis thaliana and in vegetable plants on using preparative native continuous polyacrylamide gel electrophoresis (PNC-PAGE). Electroanalysis, 18, 103-106.

Kumar, G. P., \& Prasad, M. N. V. (2004). Cadmium-inducible proteins in Ceratophyllum demersum L. (a fresh water macrophyte): Toxicity bioassays and relevance to cadmium detoxification. Bulletin of Environmental Contamination and Toxicology, 73, 174-181.

Küpper, H., Lombi, E., Zhao, F. J., \& McGrath, S. P. (2000). Cellular compartmentation of cadmium and zinc in relation to other elements in the hyperaccumulator Arabidopsis halleri. Planta, 212, 75-84.

Lasat, M. M., \& Kochian, L. V. (1998). Physiological basis for $\mathrm{Zn}$ hyperaccumulation in Thlaspicaerulescens. In H. E. Flores, J. P. Lynch, \& D. Eissenstat (Eds.), Radical biology: Advances and perspectives on the function of plant roots (pp. 139-149). Rockville: American Society of Plant Physiologists.

Lasat, M. M., \& Kochian, L. V. (2000). Physiology of Zn hyperaccumulation in Thlaspi caerulescens. In N. Terry \& G. Bañuelos (Eds.), Phytoremediation of contaminated soil and water (pp. 159-169). Boca Raton: Lewis Publishers.

Liu, J. G., Liang, J. S., Li, K. Q., Zhang, Z. J., Yu, B. Y., Lu, X. L., et al. (2003). Correlations between cadmium and mineral nutrients in absorption and accumulation in various genotypes of rice under cadmium stress. Chemosphere, 52, 1467-1473.

Lombi, E., Zhao, F. J., Dunham, S. J., \& McGrath, S. P. (2000). Cadmium accumulation in populations of Thlaspi caerulescens and Thlaspi goesingense. New Phytologist, 145, 11-20.

Maestri, E., Marmiroli, M., Visioli, G., \& Marmiroli, N. (2010). Metal tolerance and hyperaccumulation: Costs and tradeoffs between traits and environment. Environmental and Experimental Botany, 68, 1-13.

McGrath, S. P., \& Zhao, F. J. (2003). Phytoextraction of metals and metalloids from contaminated soils. Current Opinion in Biotechnology, 14, 277-282.

Mejare, M., \& Bulow, L. (2001). Metal-binding proteins and peptides in bioremediation and phytoremediation of heavy metals. Trends in Biotechnology, 19, 67-73.

Memon, A. R., \& Schroder, P. (2009). Implications of metal accumulation mechanisms to phytoremediation. Environmental Science and Pollution Research, 16, 162-175.

Meyer, C. L., Kostecka, A. A., Saumitou-Laprade, P., Creach, A., Castric, V., Pauwels, M., \& Frerot, H. (2010). Variability of zinc tolerance among and within populations of the pseudometallophyte species Arabidopsis halleri and possible role of directional selection. New Phytologist, 185, 130-142.

Meyer, C. L., Peisker, D., Courbot, M., Craciun, A. R., Cazale, A. C., Desgain, D., et al. (2011). Isolation and characterization of Arabidopsis halleri and Thlaspi caerulescens phytochelatin synthases. Planta, 234(1), 83-95.

Moreno-Jimenez, E., Penalosa, J. M., Esteban, E., \& CarpenaRuiz, R. O. (2007). Mercury accumulation and resistance to mercury stress in Rumex induratus and Marrubium vulgare grown in perlite. Journal of Plant Nutrition and Soil Science, 170, 485-494.
Nriagu, J. O. (1996). A history of global metal pollution. Science, 272, 223-224.

Nriagu, J. O., \& Pacyna, J. M. (1988). Quantitative assessment of worldwide contamination of air, water and soils by trace-metals. Nature, 333, 134-139.

Olympios, C. M. (1999). Overview of soilless culture: Advantages, constraints and perspectives for its use in Mediterranean countries. Cahiers Options Méditerranéennes, 31, 307-324.

Pauwels, M., Frerot, H., Bonnin, I., \& Saumitou-Laprade, P. (2006). A broad-scale analysis of population differentiation for $\mathrm{Zn}$ tolerance in an emerging model species for tolerance study: Arabidopsis halleri (Brassicaceae). Journal of Evolutionary Biology, 19, 1838-1850.

Persson, D., Hansen, T. H., Holm, P. E., Schjørring, J. K., Cakmak, I., \& Husted, S. (2006). Multi-elemental speciation analysis of barley genotypes differing in tolerance to Cd toxicity using LC-ICP-MS and ESI-TOF-MS. Journal of Analytical Atomic Spectrometry, 21, 996-1005.

Polatajko, A., Azzolini, M., Feldmann, I., Stuezel, T., \& Jakubowski, N. (2007). Laser ablation-ICP-MS assay development for detecting Cd- and Zn-binding proteins in Cd-exposed Spinacia oleracea L. Journal of Analytical Atomic Spectrometry, 22, 878-887.

Polatajko, A., Feldmann, I., Hayen, H., \& Jakubowski, N. (2011). Combined application of a laser ablation-ICP-MS assay for screening and ESI-FTICR-MS for identification of a Cd-binding protein in Spinacia oleracea L. after exposure to Cd. Metallomics, 3, 1001-1008.

Przedpelska, E., \& Wierzbicka, M. (2007). Arabidopsis arenosa (Brassicaceae) from a lead-zinc waste heap in southern Poland-A plant with high tolerance to heavy metals. Plant and Soil, 299, 43-53.

Rauser, W. E. (1984). Isolation and partial purification of cadmium-binding protein from roots of the grass Agrostis gigantea. Plant Physiology, 74, 1025-1029.

Robbins, J. A., \& Evans, M. R. (2005). Growing media for container production in a greenhouse or nursery: Part I (components and mixes). Fayetteville: University of Arkansas.

Roosens, N., Verbruggen, N., Meerts, P., Ximénez-Embun, P., \& Smith, J. A. C. (2003). Natural variation in cadmium tolerance and its relationship to metal hyperaccumulation for seven populations of Thlaspi caerulescens from western Europe. Plant, Cell \& Environment, 26, 1657-1672.

Sabolic, I., Ljubojevic, M., Herak, K. C. M., \& Brow, D. (2002). Cd-MT cause endocytosis of brush-border transporters in rat proximal tubules. American Journal of Physiology. Renal Physiology, 283, 1389-1402.

Sobrino-Plata, J., Ortega-Villasante, C., Flores-Caceres, M. L., Escobar, C., Del Campo, F. F., \& Hernandez, L. E. (2009). Differential alterations of antioxidant defenses as bioindicators of mercury and cadmium toxicity in alfalfa. Chemosphere, 77, 946-954.

Strebeyko, P. (1967). Introduction to plant physiology. Warsaw: PWRiL.

Szpunar, J. (2005). Advances in analytical methodology for bioinorganic speciation analysis: Metallomics, metalloproteomics and heteroatom-tagged proteomics and metabolomics. Analyst, 130, 442-465.

Vazquez, S., \& Carpena-Ruiz, R. O. (2005). Use of perlite in cadmium plant studies: An approach to polluted soil conditions. Journal of Environmental Monitoring, 7, 1355-1358. 
Verbruggen, N., Hermans, C., \& Schat, H. (2009). Molecular mechanisms of metal hyperaccumulation in plants. New Phytologist, 182, 781-781.

Wierzbicka, M. H., Przedpełska, E., Ruzik, R., Ouerdane, L., Połeć-Pawlak, K., Jarosz, M., Szpunar, J., \& Szakiel, A. (2007). Comparison of the toxicity and distribution of cadmium and lead in plant cells. Protoplasma, 231, 99-111.

Woolhouse, H. W. (1983). Toxicity and tolerance in the responses of plants to metals. In O. L. Lange, P. S. Nobel, C. B. Osmond, \& H. Ziegler (Eds.), Encyclopedia of plant physiology: Physiological plant ecology (pp. 245-310). Berlin: Springer.

Yanai, J., Zhao, F. J., McGrath, S. P., \& Kosaki, T. (2006). Effect of soil characteristics on Cd uptake by the hyperaccumulator
Thlaspi caerulescens. Environmental Pollution, 139, 167175.

Yang, X. E., Long, X. X., Ye, H. B., He, Z. L., Stoffella, P. J., \& Calvert, D. V. (2004). Cadmium tolerance and hyperaccumulation in a new Zn-hyperaccumulating plant species (Sedum alfredii Hance). Plant and Soil, 259, 181-189.

Zhang, G. P., Fukami, M., \& Sekimoto, H. (2002). Influence of cadmium on mineral concentrations and yield components in wheat genotypes differing in Cd tolerance at seedling stage. Field Crops Research, 77, 93-99.

Zhao, F. J., Jiang, R. F., Dunham, S. J., \& McGrath, S. P. (2006). Cadmium uptake, translocation and tolerance in the hyperaccumulator Arabidopsis halleri. New Phytologist, 172, 646-654. 